\title{
Production of IGF-I and IGF binding proteins by retinal cells in vitro
}

\author{
Patrick Moriarty, Mike Boulton, Alan Dickson, David McLeod
}

\begin{abstract}
Insulin-like growth factor I (IGF-I) and its associated binding proteins (IGFBPs) have been identified in retinal tissues but their precise cellular origin remains unclear. The aim of this study was to examine the ability of three retinal cell types (microvascular endothelial cells, pericytes, and pigment epithelial cells) and a non-retinal cell type (Tenon's fibroblasts) to produce IGF-I and cell specific IGFBPs in vitro. Using a radioimmunoassay we demonstrated that all four cell types produce IGF-I and that this production continued over a 72 hour period. In addition, western ligand blotting revealed that each cell type produced at least one IGFBP and that each cell type produced a different IGFBP profile. Endothelial cells produced a $24 \mathrm{kDa}$ band only, pericytes produced both a $24 \mathrm{kDa}$ and a $34 \mathrm{kDa}$ band, retinal pigment epithelial cells produced a 38-41 kDa band, while fibroblasts produced both a $24 \mathrm{kDa}$ and a $30 \mathrm{kDa}$ band. Laser scanning densitometry demonstrated that in the majority of experiments the IGFBPs accumulated in the culture medium over a 72 hour period. Neither IGF-I nor IGFBPs were observed in cell lysates indicating de novo synthesis and secretion in vitro. These results suggest an autocrine/paracrine function for IGF-I and its associated binding proteins which may play a significant role in both retinal physiology and disease.
\end{abstract}

(Brf Ophthalmol 1994; 78: 638-642)

Insulin-like growth factor I (IGF-I) is a polypeptide which stimulates the growth, differentiation, and metabolism of a variety of cell types.' Its activity is controlled in a complex manner for example, IGF-I expression in most tissues is known to be influenced by hormonal, nutritional, tissue specific, and developmental factors. $^{2-5}$ In addition it appears that the growth promoting effects of many circulating hormones may be mediated via the stimulation of local IGF-I production.'

IGF-I activity in extracellular fluids is carefully controlled by its association with insulin-like growth factor binding proteins (IGFBPs) ${ }^{6}$ Like IGF-I, the IGFBPs appear to be produced from a variety of cell types ${ }^{4}$; six distinct binding proteins have been cloned, sequenced, and given a uniform nomenclature. ${ }^{78}$ Their principal functions range from acting merely as transport vehicles for IGF-I/IGF-II to playing an integral role in overall IGF-I physiology. ${ }^{+7} \mathrm{~A}$ further determinant of IGF-I function is its binding to specific cell surface receptors which include the closely related insulin and IGF-I receptors and the IGF-II/mannose-6-phosphate receptors, each of which exhibit varying affinities for IGF-I. Thus, the interaction of IGF-I, IGFBPs, and a family of closely related receptors is responsible for the net effect of IGF-I on target cell function.

Evidence suggests that IGF-I may play an important role in retinal development and physiology. The adult neural retina from a variety of species has been shown to express both the IGF-I and the IGF-I receptor gene $\mathrm{e}^{9-11}$ and IGF-I receptors have been localised to the inner and outer segments of photoreceptor cells. ${ }^{12-14}$ Large numbers of IGF-I binding sites have been identified in the embryonic chick retina ${ }^{1516}$ and it is also becoming apparent that the whole spectrum of IGFBPs are present in ocular tissues. ${ }^{17-20}$ While the origin of these binding proteins remains largely unknown, recent evidence has demonstrated the expression of two major IGFBPs, IGFBP-2 and IGFBP-3, in the cornea, iris/ ciliary body complex, and the retina. ${ }^{1821}$

The characterisation of both IGF-I and their associated binding proteins in ocular cells remains incomplete. The aim of this study was, therefore, to investigate the production of both IGF-I and IGFBP isoforms by four ocular cell types in vitro.

\section{Materials and methods}

\section{CELL CULTURE}

Retinal microvascular endothelial cells, retinal pericytes, and Tenon's capsule fibroblasts (a control non-intraocular cell type used throughout this study) were isolated from bovine eyes as previously described. ${ }^{22}$ Endothelial cells were grown on gelatin (Sigma Chemical Co, St Louis, MO, USA) coated $35 \mathrm{~mm}$ dishes (Falcon) and maintained in a 1:1 mixture of Dulbecco's modified Eagles medium (DMEM) plus $7 \cdot 5 \%(\mathrm{v} / \mathrm{v})$ human platelet-poor plasma with pericyte conditioned medium ${ }^{22}$ supplemented with $20 \mu \mathrm{l} / \mathrm{ml}$ bovine retinal crude extract ${ }^{23}$ and $90 \mu \mathrm{g} / \mathrm{ml}$ heparin (Sigma). Pericytes and fibroblasts were routinely grown in $25 \mathrm{~cm}^{3}$ tissue culture flasks (Falcon) and maintained in DMEM supplemented with $20 \%$ heat inactivated fetal calf serum (FCS) (Northumbria Biologicals) and antibiotics.

Retinal pigment epithelial (RPE) cells were isolated from donor human eyes as previously described. ${ }^{24}$ RPE cells were routinely grown in $75 \mathrm{~cm}^{3}$ tissue culture flasks (Costar) and maintained in Ham's F10 supplemented with $20 \%$ FCS, antibiotics, and $0.4 \%$ glucose $(\mathrm{BDH})$. All cells were routinely incubated at $37^{\circ} \mathrm{C}$ in a standard 5\% carbon dioxide $/ 95 \%$ air incubator. In all experiments, each cell type was used between second and fifth passage. Confirmation 
of the purity of the cultures was carried out as previously described..$^{225}$

GROWTH FACTOR PROFILES OF RETINAL CELLS Cells were detached using $0 \cdot 25 \%(\mathrm{v} / \mathrm{v})$ trypsin (Difco) and plated into 24 well plates in their respective media (in the case of endothelial cells the wells were precoated with gelatin). Upon confluence, cells were washed twice in Dulbecco's phosphate buffered saline (PBS) and the medium was replaced with either DMEM supplemented with $7 \cdot 5 \%(\mathrm{v} / \mathrm{v})$ human plateletpoor plasma or plasma-free DMEM. Cells were incubated in the two types of media till the following time points: $0,6,12,24,48$, and 72 hours. After each time point the 'conditioned' media were removed and the cells washed twice with PBS and lysed with $0.5 \%$ Triton X-100, $20 \mathrm{mM} \mathrm{NH} \mathrm{NH}_{4} \mathrm{OH}$, and $0.1 \%$ serum albumin in PBS. Both sets of samples were centrifuged at $3000 \mathrm{~g}$. to remove cell debris and the supernatants stored at $-20^{\circ} \mathrm{C}$ before assessment for IGF-I and IGFBPs. Additional wells were used for cell counts at each time point using a haemocytometer. All experiments were performed with confluent monolayers, using six wells per time point for each cell type and the experiments repeated at least three times for each cell type.

EXTRACTION AND RADIOIMMUNOASSAY FOR IGF-I Before the assay of culture medium for IGF-I, IGFBPs were removed from the media samples by acid-ethanol extraction. ${ }^{26}$ Briefly, media samples $(200 \mu \mathrm{l})$ were incubated for 30 minutes at room temperature with $800 \mu$ l of an extraction mixture $(87 \cdot 5 \%$ ethanol/12.5\% $2 \mathrm{M} \mathrm{HCl}, \mathrm{v} / \mathrm{v})$. Extracted media samples were then centrifuged at $1850 \mathrm{~g}$ for 30 minutes. A $500 \mu \mathrm{l}$ aliquot of the supernatant was then transferred into fresh tubes and neutralised with $0.855 \mathrm{M}$ Tris $(\mathrm{pH} \mathrm{11)}$ at a ratio of 5:2. IGF-I within the culture media extracts was assayed against human IGF-I (International Reference Preparation coded 87/518; National Institute of Biological Standards and Control, Potters Bar, Herts), serially diluted over the range $0 \cdot 1-125 \mathrm{ng} / \mathrm{ml}$ in radioimmunoassay (RIA) buffer (PBS plus $0 \cdot 1 \%(\mathrm{v} / \mathrm{v})$ Tween-20, and $0 \cdot 1 \%(\mathrm{w} / \mathrm{v})$ bovine serum albumin) and extracted in an identical fashion to the media samples. The RIA reaction mixture comprised $100 \mu{ }^{125}$ I-IGF-I, $100 \mu \mathrm{l}$ unlabelled IGF-I (in the case of standard/test samples) and $100 \mu \mathrm{l}$ polyclonal rabbit anti-human IGF-I antiserum (donated by $\mathrm{Dr}$ Helen Beere, Manchester University) at a dilution of $1: 37500$. Reagent additions were carried out on ice and the tubes were incubated overnight at $4^{\circ} \mathrm{C}$. After incubation, $100 \mu \mathrm{l}$ of anti-rabbit IgG coated with cellulose (IDS) was added to each reaction tube except those for total counts. The mixtures were incubated for 1 hour at $37^{\circ} \mathrm{C}$. Thereafter, $0.5 \mathrm{ml}$ of RIA buffer was added and the tubes were centrifuged at $1850 \mathrm{~g}$ for 15 minutes. The supernatant was discarded, and the pellet was assayed on a gammacounter. In addition, endogenous levels of IGF-I were determined in plasma-containing media which had not been exposed to cells.
WESTERN LIGAND BLOTTING

Media IGFBPs were identified using methods previously described. ${ }^{26}$ Media samples were subjected to non-reducing SDS-PAGE (12.5\% gel) under $100 \mathrm{~V}$ (continuous voltage) and then transferred to nitrocellulose filters $(0.45 \mu \mathrm{m}$ pore size).

Ligand blot analysis was performed at $37^{\circ} \mathrm{C}$ essentially as described by Hossenlopp, ${ }^{27}$ in brief, the nitrocellulose membranes were sequentially blocked for 30 minutes in Tris-buffered saline (TBS; $10 \mathrm{mM}$ Tris/ $\mathrm{HCl}$ and $0.15 \mathrm{M} \mathrm{NaCl}, \mathrm{pH}$ 7.4) containing 3\% Nonidet P-40 (Sigma); 2 hours in TBS containing $1 \%$ bovine serum albumin, and. finally, 10 minutes in TBS containing $0 \cdot 1 \%$ Tween 20 . Binding of ${ }^{125}$ I-IGF-II $\left(1 \times 10^{6} \mathrm{cpm} / 5 \mathrm{ml}\right)$ to the blot was conducted for 3 hours in a sealed plastic bag in TBS containing $1 \%$ bovine serum albumin and $0 \cdot 1 \%$ Tween 20 . Thereafter, the nitrocellulose membrane was washed twice in TBS plus $0 \cdot 1 \%$ Tween 20 , and then three times in TBS alone. The membranes were air dried. A range of prestained molecular weight markers were run in a parallel lane to confirm the molecular weights of each band. Bands were visualised by autoradiography and the relative signals were quantitated by scanning densitometry. Comparative studies were also carried out using ${ }^{125} \mathrm{I}-\mathrm{IGF}-\mathrm{I}\left(1 \times 10^{6} \mathrm{cpm} / 5 \mathrm{ml}\right)$ as the radioligand.

\section{Results}

All cell types maintained under plasma-free conditions released detectable levels of IGF-I throughout the time course of this study (Fig 1). However, IGF-I production in plasmacontaining media was restricted to the RPE cells and only at the 72 hour time point by which time IGF-I levels were greater than the endogenous level in plasma-containing medium (15 (SD 1) $\mathrm{ng} / \mathrm{ml})$. The release of IGF-I into plasma-free medium varied between cell types (Fig 1). Both pericytes and RPE cells continually produced IGF-I throughout the time course of the study.

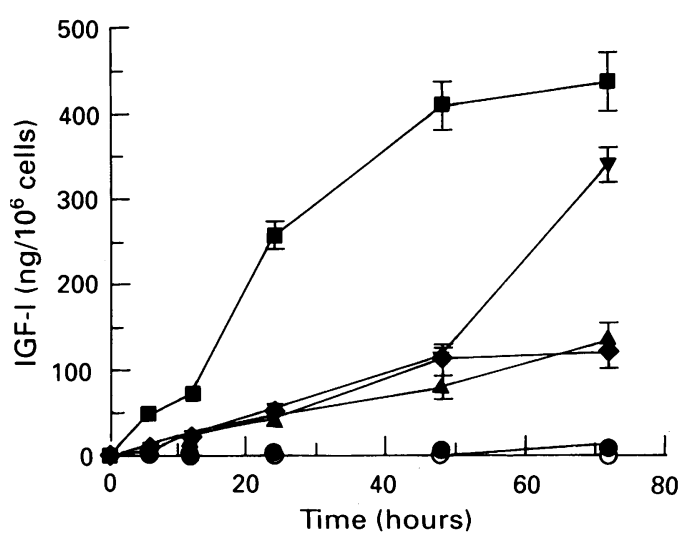

Figure 1 Production of IGF-I by retinal microvascular endothelial cells, pericytes, RPE cells, and Tenon fibroblasts in plasma-free and plasma-containing media over a period of 72 hours. Plasma-free medium: retinal microvascular endothelial cells ( $\mathbf{\square})$, pericytes $(\mathbf{\Delta}), R P E$ cells $(\boldsymbol{\nabla})$, and Tenon fibroblasts (C). Plasma-containing medium: retinal microvascular endothelial cells and Tenon fibroblasts $(\mathrm{O})$, RPE cells (O). For plasma containing media the endogenous IGF-I levels in 'unconditioned' media (15 (SD l) ng/ml) were subtracted from the total IGF-I present at each time point. The values presented are the mean of three experiments. The vertical bars represent SEM. 
$\mathrm{Mr} \times 10^{-3}$

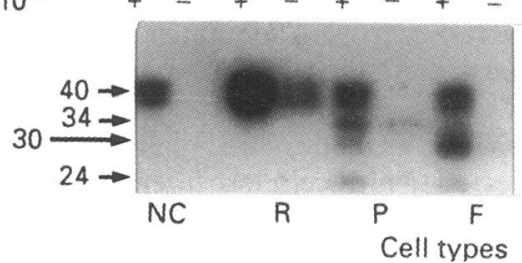

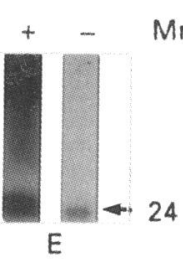

Figure 2 Western ligand blot of IGFBPs produced by the four ocular cell types in the presence $(+)$ or absence (-) of plasma. $N C=$ no cells; $R=$ retinal pigment epithelium cells; $P=$ pericytes; $F=$ Tenon's fibroblasts; $E=$ retinal microvascular endothelia cells. The estimated $\mathrm{Mr}$ $(k D a)$ of each form was derived by comparison with defined Mr standards. This autoradiograph was representative of three separate experiments. threefold higher at the 72 hour time point.
By contrast, production of IGF-I by endothelial cells and fibroblasts was continuous up to 48 hours and began to level off after 48 hours. Retinal microvascular endothelial cells produced the highest levels of IGF-I at each time point. Pericytes and fibroblasts produced similar levels of IGF-I over the 72 hour period. However, while RPE cells demonstrated similar levels of IGF-I to pericytes and fibroblasts over the first 48 hours the levels of IGF-I were approximately

Cell numbers for retinal microvascular endothelial cells, pericytes, and RPE cells remained constant in both plasma-containing and plasmafree medium throughout the time course of the experiment. Cell numbers for fibroblasts remained constant in plasma-containing medium throughout the experimental period but those in plasma-free medium showed a $50 \%$ reduction in cell numbers after 48 hours.

Each cell type studied produced a distinct IGFBP profile which was identical in both the plasma-containing and plasma-free media (Fig 2 ), however, the production of IGFBPs in plasma-free medium was greatly reduced compared with that in plasma-containing medium. In the case of plasma-containing media IGFBP profiles were clearly distinguishable from the endogenous IGFBPs in the plasma (predominantly a $38-41 \mathrm{kDa}$ band). No bands were observed in the plasma-free media that had not been exposed to cells.

Endothelial cells produced a $24 \mathrm{kDa}$ band only. Pericytes produced two IGFBPs, one at 34 $\mathrm{kDa}$ and a faint band at $24 \mathrm{kDa}$. RPE cells produced a $38-41 \mathrm{kDa}$ band only while fibroblasts produced a $30 \mathrm{kDa}$ and a faint band at 24 $\mathrm{kDa}$. Identical IGFBPs profiles were observed using ${ }^{125}$ I-IGF-I as the ligand.

Results from both western ligand blotting and subsequent densitometric analysis depicted differential production of IGFBPs with respect to time, media type, and IGFBP type (Figs 3-6; Table I). In all cases IGFBP accumulation in the culture media was greatest at the 72 hour time point, but the rate of accumulation varied with cell type. Ultrascan data for endothelial cell production of the $24 \mathrm{kDa}$ IGFBP showed a slight variation between the two types of media; production in the plasma-containing media was continuous and similar to that observed for their production of IGF-I (Fig 1), while production in the plasma-free media increased steadily from 12 to 48 hours whereupon the levels of IGFBP remained constant. By contrast, retinal pericyte production of the predominant $34 \mathrm{kDa}$ and the $24 \mathrm{kDa}$ IGFBP depicted similar trends of accumulation in both media types (that is, the production of both increased steadily as a function of time).

Production of the $38-41 \mathrm{kDa}$ IGFBP by RPE cells appeared to follow no trend in the plasmacontaining media, whereas in the plasma-free media production increased rapidly with time (identical to RPE production of IGF-I). Fibroblast production of both the $30 \mathrm{kDa}$ and $24 \mathrm{kDa}$ IGFBPs peaked at 48 hours in the plasmacontaining media, after which time it decreased dramatically (indicative of proteolytic degradation). By contrast, production of the $30 \mathrm{kDa}$ IGFBP remained relatively constant after 12 hours of production in the plasma-free medium (although a peak of production was observed at 72 hours); after a 6 hour lag period production of the $24 \mathrm{kDa}$ IGFBP was continuous with time in the plasma-free media. The $24 \mathrm{kDa}$ IGFBP

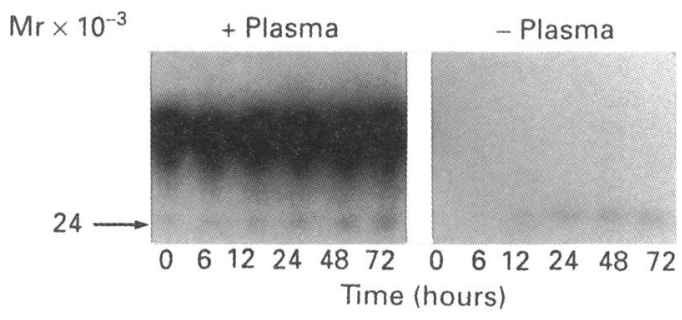

Figure 3 Western ligand blot showing the production of the $24 \mathrm{kDa} I G F B P$ by endothelial cells over a 72 hour timecourse. The time course experiments were carried out in the presence (+ plasma) and the absence (-plasma) of plasma. This autoradiograph was representative of three separate experiments.

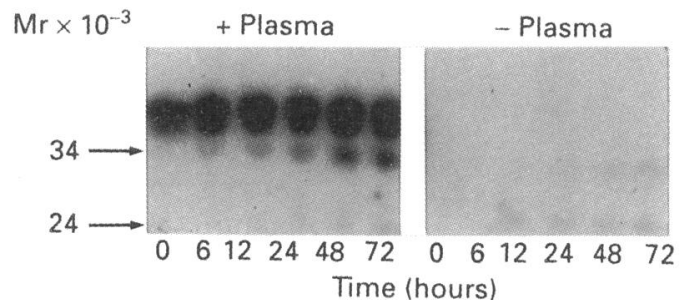

Figure 4 Western ligand blot showing the production of both the 24 and $34 k D a I G F B P$ s by pericytes over a 72 hour time course. The time course experiments were carried out in the presence (+plasma) and the absence (-plasma) of plasma. This autoradiograph was representative of three separate experiments.

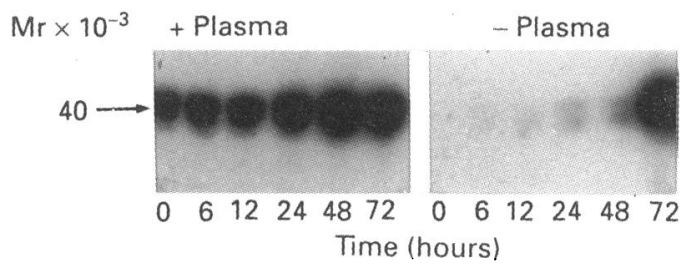

Figure 5 Western ligand blot showing the production of the 38-41 IGFBP produced by RPE cells over a 72 hour time course. The time course experiments were carried out in the presence (+plasma) and the absence (-plasma) of plasma. This autoradiograph was representative of three separate experiments.

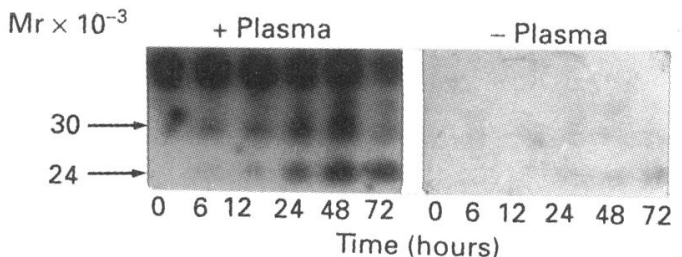

Figure 6 Western ligand blot showing the production of both the 30 and $24 \mathrm{kDa}$ IGFBPs by Tenon's fibroblasts over a 72 hour time course. The time course experiments were carried out in the presence (+plasma) and the absence (-plasma) of plasma. This autoradiograph was representative of three separate experiments. 
Table 1 Densitometric analysis of the IGFBP bands generated by western ligand blotting as shown in Figures 3-6. Densitometric measurements are given in arbitrary units

\begin{tabular}{|c|c|c|c|c|c|c|c|c|}
\hline \multirow{2}{*}{$\begin{array}{l}\text { Cell } \\
\text { type }\end{array}$} & \multirow{2}{*}{$\begin{array}{l}\text { IGFBP } \\
(k D a)\end{array}$} & \multirow{2}{*}{$\begin{array}{l}\text { Media type } \\
(+1-\text { plasma })\end{array}$} & \multicolumn{6}{|c|}{ Time (hours) } \\
\hline & & & 0 & 6 & 12 & 24 & 48 & 72 \\
\hline Endothelial & 24 & $\begin{array}{l}+ \\
-\end{array}$ & $\begin{array}{l}0.06 \\
\text { ND }\end{array}$ & $\begin{array}{l}0 \cdot 10 \\
\text { ND }\end{array}$ & $\begin{array}{l}0.15 \\
0.07\end{array}$ & $\begin{array}{l}0 \cdot 19 \\
0 \cdot 11\end{array}$ & $\begin{array}{l}0 \cdot 21 \\
0 \cdot 12\end{array}$ & $\begin{array}{l}0 \cdot 24 \\
0 \cdot 11\end{array}$ \\
\hline \multirow[t]{2}{*}{ Pericyte } & 34 & $\begin{array}{l}+ \\
-\end{array}$ & $\begin{array}{l}\text { ND } \\
\text { ND }\end{array}$ & $\begin{array}{l}0.08 \\
\text { ND }\end{array}$ & $\begin{array}{l}0.34 \\
0.01\end{array}$ & $\begin{array}{l}0.40 \\
0.02\end{array}$ & $\begin{array}{l}0 \cdot 80 \\
0.03\end{array}$ & $\begin{array}{l}0 \cdot 90 \\
0 \cdot 10\end{array}$ \\
\hline & 24 & + & $\begin{array}{l}\text { ND } \\
\text { ND }\end{array}$ & $\begin{array}{l}\text { ND } \\
\text { ND }\end{array}$ & $\begin{array}{l}\text { ND } \\
0.02\end{array}$ & $\begin{array}{l}0.02 \\
0.04\end{array}$ & $\begin{array}{l}0.03 \\
0.06\end{array}$ & $\begin{array}{l}0.08 \\
0 \cdot 15\end{array}$ \\
\hline RPE & $38-41$ & $\begin{array}{l}+ \\
-\end{array}$ & $\begin{array}{l}3 \cdot 6 \\
\text { ND }\end{array}$ & $\begin{array}{l}4 \cdot 7 \\
0.05\end{array}$ & $\begin{array}{l}4 \cdot 3 \\
0.08\end{array}$ & $\begin{array}{l}6 \cdot 3 \\
0 \cdot 1\end{array}$ & $\begin{array}{l}7 \cdot 8 \\
0 \cdot 4\end{array}$ & $\begin{array}{l}7 \cdot 0 \\
8 \cdot 6\end{array}$ \\
\hline \multirow[t]{2}{*}{ Fibroblast } & 30 & $\begin{array}{l}+ \\
-\end{array}$ & $\begin{array}{l}\text { ND } \\
\text { ND }\end{array}$ & $\begin{array}{l}0.52 \\
0.02\end{array}$ & $\begin{array}{l}0.53 \\
0.03\end{array}$ & $\begin{array}{l}0.90 \\
0.03\end{array}$ & $\begin{array}{l}1 \cdot 1 \\
0 \cdot 03\end{array}$ & $\begin{array}{l}0.30 \\
0.06\end{array}$ \\
\hline & 24 & $\begin{array}{l}+ \\
-\end{array}$ & $\begin{array}{l}\text { ND } \\
\text { ND }\end{array}$ & $\begin{array}{l}0.04 \\
\text { ND }\end{array}$ & $\begin{array}{l}0.05 \\
0.01\end{array}$ & $\begin{array}{l}0.35 \\
0.04\end{array}$ & $\begin{array}{l}0.90 \\
0.07\end{array}$ & $\begin{array}{l}0 \cdot 71 \\
0 \cdot 20\end{array}$ \\
\hline
\end{tabular}

$\mathrm{ND}=$ Not detectable. The data presented are the mean of one experiment. It was impossible to combine the data from different experiments owing to between-experiment variation in labelling for specific activity for probes in ligand-binding analysis and different exposure times for $x$ ray films. However, the same trend in band intensity was observed in each experiment.

appeared to demonstrate a lag period of up to 24 hours before its accumulation could be observed in the media for those cell types responsible for its production.

No detectable IGF-I or IGFBPs were observed in the cell lysates for each of the four cell types studied at any time point.

\section{Discussion}

This study has demonstrated (a) that retinal cells simultaneously secrete both IGF-I and IGFBPs, and (b) that the profiles of IGFBPs secreted are dependent on cell type.

Our results support and extend those of Brooks and associates ${ }^{28}$ and Waldbillig and associates $^{12} 29$ who have demonstrated that both retinal microvascular endothelial cells and RPE cells produce IGF-I in vitro. It is difficult to make comparisons between the levels of IGF-I produced in the various studies owing to the different extraction procedures used before radioimmunoassay and the different cell culture conditions (it is likely that the levels of IGF-I produced by individual cell types are media dependent). While observing different levels of IGF-I production between human and bovine cells this study does not take into account possible species specific, post-translational modification of IGF-I that may occur in bovine cells when compared with human cells.

The apparent lack of production of IGF-I in serum/plasma-containing media is supported by (a) Brooks et al ${ }^{28}$ who observed IGF-I production by bovine microvascular cells in serum-free medium but failed to observe IGF-I production in serum-containing medium, and (b) Lowe et $a l^{30}$ who concluded that serum factors may inhibit IGF-I production. This discrepancy between IGF-I levels in plasma-free versus plasma-containing medium can be explained in one of two ways. Firstly, there may be negative feedback on the production of IGF-I by retinal cells owing to the presence of endogenous IGF-I in the plasma $(15 \mathrm{ng} / \mathrm{ml})$ as postulated by Brooks et al. However, this is unlikely since IGF-I production was observed in plasma-free medium at IGF-I levels greater than $40 \mathrm{ng} / \mathrm{ml}$. It is possible, however, that other endogenous factors in plasma are capable of inhibiting IGF-I production; transforming growth factor $\beta$ has been shown to downregulate IGF-I production in vitro. ${ }^{31}$ Secondly, the inability to measure IGF-I in plasma-containing media may be due to the effect of plasma on the extraction procedure. The sensitivity of the RIA is reduced 15-fold when IGF-I extraction is undertaken in the presence of plasma as opposed to plasma-free medium (results not shown). Thus it is plausible that the cells were indeed secreting IGF-I in the plasmacontaining medium but that it remained below the sensitivity of the RIA. Support for this explanation comes from the fact that IGFBP secretion was seen in both the plasma-containing and plasma-free media.

This study is the first to demonstrate that retinal cells secrete cell-specific IGFBP profiles in a time-dependent manner in vitro. Although western ligand blotting enables the identification of IGFBPs by molecular weight, this technique does not have the positive advantages of immunoblotting or RIA which categorically identify each IGFBP isoform. However, the recent discovery of IGFBP proteases present in a variety of biological fluids necessitates a comprehensive re-evaluation of techniques for assaying IGFBPs. ${ }^{42}$ Nevertheless, on the basis of molecular weight the following IGFBP isoforms can be tentatively identified: $38-41 \mathrm{kDa}=\mathrm{IGFBP}-3,34$ $\mathrm{kDa}=\mathrm{IGFBP}-2,30 \mathrm{kDa}=\mathrm{IGFBP}-1$, and 24 $\mathrm{kDa}=\mathrm{IGFBP}-4 .{ }^{47}$ The only previous reports on IGFBP production by retinal cells in vitro relate to RPE cells. Waldbillig and associates ${ }^{29}$ reported that monkey RPE secreted a broad band of IGFBPs between 36 and $49 \mathrm{kDa}$ which failed to accumulate in the culture medium beyond 12 hours' incubation indicative of IGFBP degrading activity in the culture system. Ocrant and associates $^{20}$ observed a $31 \mathrm{kDa}$ band for bovine RPE. By contrast, we observed a continuous production of a well defined $38-41 \mathrm{kDa}$ band (tentatively identified as IGFBP-3) by human RPE cells throughout the time course of the experiment. While species variation cannot be ruled out, only definitive sequence data can explain the reasons for these differences.

That IGF-I and its associated binding proteins accumulate in the conditioned media of ocular cells does not necessarily indicate the release of previously internalised IGF-I or IGFBPs (a phenomenon known to occur in endothelial cells ${ }^{32}$ ) since cell lysates did not demonstrate detectable levels of either IGF-I or IGFBPs. However, the production of both IGF-I and the IGFBPs may be significantly higher than the values reported here since internalisation and degradation may have been occurring during the time course of the experiments.

The individual roles that IGFBPs play in overall IGF-I physiology is still unclear. While some reports suggest an inhibitory role by restricting access to receptors, others have suggested that IGFBPs facilitate growth by augmenting interaction with receptors, thus potentiating a mitogenic response. ${ }^{+7}$ Nearly all binding proteins have been shown to be capable of exerting both stimulatory and inhibitory effects, depending on the cell culture conditions, cell type, etc. ${ }^{1+}$

This study demonstrates that the retina contains all the components of a self-contained IGF- 
I/IGFBP autocrine/paracrine system which may play an important role in retinal physiology and disease - for example, in proliferative diabetic retinopathy (PDR). ${ }^{17}{ }^{33}$ All the retinal cell types studied produced IGF-I at concentrations in excess of those reported to stimulate their proliferation, ${ }^{34}$ their migration, ${ }^{35}$ and the release of enzymes in the plasminogen cascade,${ }^{36}$ which are associated with the cellular events in diabetic neovascularisation. ${ }^{37}$ It is becoming increasingly apparent that both the type and amount of IGFBPs will variously affect the ability of IGF-I to associate with cell-surface binding sites. ${ }^{4}$ The observation that autocrine/paracrine-derived IGF-I has a decreased affinity for its associated binding proteins ${ }^{38}$ compared with endocrine derived IGF-I may imply that the autocrine/ paracrine production of IGFBPs is of limited significance under normal conditions but may have a role in disease states such as PDR where the contribution from serum-derived IGF-I is more prominent.

In conclusion, the data presented here clearly demonstrate that all three retinal cell types studied are capable of producing both IGF-I and cell-specific IGFBP(s) in vitro. However, exactly how this IGF-I/IGFBP system operates to maintain the homeostasis of the retina, and how its role changes in retinal diseases, requires further investigation.

This study was supported by Fight for Sight, the Iris Fund, the Wellcome Trust, and the ment Fund.

1 Zapf J, Schmidt C, Froesch E. Biological and immunological properties of insulin-like growth factors (IGF) I and II. Clin properties of insulin-like growth

2 Baxter RC, Brown AS, Turtle JR. Decrease in serum receptorreactive somatomedin in diabetes. Hormone Metab Res 1979 11: $216-20$.

3 Bornfeldt KE, Skottner A, Arnqvist HJ. In-vivo regulation of messenger RNA encoding insulin-like growth factor-I (IGFI) and its receptor by diabetes, insulin and IGF-I in rat muscle. F Endocrinol 1992; 135: 203-11.

4 Clemmons DR. IGF binding proteins and their functions. Molecular Reproduction and Development 1993; 35: 368-75.

5 Rotwein P, Bichell DP, Kikuchi K. Multifactorial regulation of IGF-I gene expression. Molecular Reproduction and Devel-
opention opment 1993; 35: 358-64.

6 Ooi GT, Herrington AC. Review: the biological and structural characteristics of specific serum binding proteins for IGFs. f Endocrinol 1988; 118: 7-18.

7 Drop SLS, Schuller AGP, Lindenbergh-Kortleve DJ, Groffen C, Brinkman A, Zwarthoff EC. Structural aspects of the IGFBP family. Growth Regulation 1992; 2: 69-79.

8 Ballard FJ, Baxter RC, Binoux M. On the nomenclature of the IGFBPs. $\mathcal{f}$ Clin Endocrinol Metab 1990; 70: 817-8.

9 Danias J, Stylianopoulou F. Expression of IGF-I and IGF-II genes in the adult rat eye. Curr Eye Res 1990; 9: 379-86.

10 Han VMK, D'Ercole AJ, Lund PK. Cellular localisation of somatomedin (insulin-like growth factor) messenger RNA in the human fetus. Science 1987; 236: 193-7.

11 Boulton ME, Patel B, Khaliq A, Moriarty PA, Jarvis-Evans J, McLeod D. Modulators and milieu in preretinal neovascularisation. Eye 1992; 6: 560-5.

12 Waldbillig RJ, Pfeffer B, Schoen TJ, Adler A, Shen-Orr Z, Scavo L, et al. Evidence for an insulin-like growth factor-I autocrine-paracrine system in the retinal photoreceptorpigment epithelium cell complex. $\mathcal{F}$ Neurochem 1991; 57: 1522-33.

13 Zick Y, Spiegel AM, Sagi-Eisenberg R. Insulin-like growth factor-I receptors in retinal ROS outer segments. $\mathcal{F} \mathrm{Biol}$ Chem 1987; 262: 10259-64.
14 Ocrant T, Valentino KL, King MG, Wimpy TH, Rosenfeld RG, Baskin DG. Localisation and structural characterisation of insulin-like growth factor receptor in mammalian retina. of insulin-like growth factor receptor

15 Bassnett S, Beebe DC. Localisation of insulin-like growth factor binding sites in the embryonic chick eye. Invest Ophthalmol Vis Sci 1990; 31: 81-93.

16 Waldbillig RJ, Arnold D, Fletcher RT, Chader GJ. Insulin and IGF-I binding in the developing chick neural retina and pigment epithelium: a characterisation of binding and structural differences. Exp Eye Res 1991; 52: 13-22.

17 Grant M, Russell R, Fitzgerald C, Merimee T. Insulin-like growth factors in the vitreous: studies in control and diabetic growth factors in the vitreous: studies in control and diabetic
subjects with neovacularisation. Diabetes 1986; 35: 416-20.

18 Arnold DR, Moshayedi P, Schoen TJ, Jones BE, Chader GJ, Waldbillig RJ. Distribution of IGF-I and IGF-II, IGF Winding proteins (IGFBPs) and IGFBP mRNA in ocular binding proteins (IGFBPs) and IGFBP mRNA in ocular
fluids and tissues: potential sites of synthesis of IGFBPs in fluids and tissues: potential sites of synthesis of IGF

19 Schoen TJ, Beebe DC, Clemmons DR, Chader GJ, Waldbillig $R J$. Local synthesis and independent developmental regulation of avian vitreal insulin-like growth factor binding proteins: a model for the independent developmental regulation in vascular and extravascular compartments. Endocrinology 1992; 131: 2846-54.

20 Ocrant I, Fay T, Parmelee JT. Expression of insulin and insulin-like growth factor receptors and binding proteins by retinal pigment epithelium. Exp Eye Res 1991; 52: 581-9.

21 Agarwal N, Hsieh CL, Sills D, Swaroop M, Desai B, Francke $\mathrm{U}$, et al. Sequence analysis, expression and chromosomal localisation of a gene isolated from a subtracted human retina cDNA library, that encodes an insulin-like growth factor binding protein (IGFBPs). Exp Eye Res 1991; 52: 549-61.

22 Wong HC, Boulton ME, Marshall J, Clark P. Growth of retinal microvascular endothelia using pericyte conditioned media. Invest Ophthalmol Vis Sci 1987; 28: 1767-5.

23 Gitlin JD, D'Amore PA. Culture of retinal capillary endothelial cells using selective growth media. Microvasc Res 1983; 26: 74-80.

24 Boulton ME, Marshall J, Mellerio J, Clark J. Retinitis pigmentosa: a preliminary report on tissue culture studies of retinal pigment epithelium cells from eight affected human eyes. Exp Eye Res 1983; 37: 307-13.

25 McKechnie NM, Boulton ME, Robey HL, Savage FJ, Grierson I. The cytoskeletal elements of human retinal pigment epithelium: in vitro and in vivo. $\mathcal{F}$ Cell Sci 1988; 91:303-12.

26 Daughaday WH, Parker KA, Borowsky B, Trivedi B, Kapadia $M$. Measurement of somatomedin-related peptides in fetal, neonatal, and maternal rat serum by IGF-I RIA, IGF-II RRA and multiplication-stimulating activity RRA after acidRRA and multiplication-stimulating activity RRA after

27 Hossenlopp P, Seurin D, Segovia-Quinson B, Hardouin S, Binoux M. Analysis of serum insulin-like growth factor binding proteins using western blotting: use of the method for titration of binding proteins and competitive binding studies. Anal Biochem 1986; 208: 439-44.

28 Brooks RA, Burrin JM, Kohner EM. Characterization of release of basic fibroblast growth factor from bovine retinal endothelial cells in monolater cultures. Biochem f 1991; 276: 113-20.

29 Waldbillig RJ, Schoen TJ, Chader GJ, Pfeffer B. Monkey retinal pigment epithelial cells in-vitro synthesise, secrete and degrade insulin-like growth factor binding proteins. $\mathcal{F}$ Cell Physiol 1992; 150: 76-83.

30 Lowe Wl, Kummer M, Karpen CW, Wu XD. Serum factors that may inhibit IGF-I production. Endocrinology 1990; 127: 2854-61.

31 Beere HM, Soden J, Tomlinson S, Bidey SP. Insulin-like growth factor-I production and action in porcine thyroid follicular cells in monolayer: regulation by TGF- $B$. $\mathcal{F} E$ Edocrinol 1991; 130: 3-9.

32 Bar RS, Boes M, Dake BL, Booth BA, Henley SA, Sandra A. Insulin, insulin-like growth factors, and vascular endothelium. Am f Med 1988; 85: 59-70.

33 Merimee T. Diabetic retinopathy: a synthesis of perspectives. N Engl F Med 1990; 322: 978-83.

34 King GL, Goodman AD, Buzney S, Moses A, Kahn CR. Receptors and growth-promoting effects of insulin and insulin-like growth factors on cells from bovine retinal capillaries and aorta. F Clin Invest 1985; 75: 1028-36.

35 Grant M, Jerdan J, Merimee TJ. Insulin-like growth factor-I modulates endothelial cell chemotaxis. $\mathcal{F}$ Clin Endocrinol Metab 1987; 65: 370-1

36 Grant MB, Guay C, Marsh R. Insulin-like growth factor stimulates proliferation, migration and plasminogen activator release by human pigment epithelial cells. Curr Eye Res $1190 ; 4: 323-35$.

37 Glaser BM. Extracellular modulating factors and the control of intraocular neovascularisation: an overview. Arch Ophthalintraocular neovascular

38 Sara VR, Hall R. Insulin-like growth factors and their binding proteins. Physiol Rev 1990; 70: 591-614. 